\title{
Marine Phytoplankton in Port and Ship's Ballast Water at Tanjung Priok Harbour, North Jakarta, Indonesia
}

\author{
Hikmah Thoha ${ }^{1, *}$ and Arief Rachman ${ }^{1}$ \\ 1Plankton and Primary Productivity Laboratory, Research Center for Oceanography, Indonesian Institute of Sciences, Jl. Pasir Putih \\ No. 1, Ancol Timur, North Jakarta 14430, Indonesia \\ *Corresponding author: hikmah_thoha@yahoo.com
}

\author{
KEYWORDS \\ Algal bloom \\ Community structure \\ Jump dispersal \\ Non-indigenous
}

\begin{abstract}
This research aimed to study the phytoplankton community in ships' ballast water in comparison with the natural assemblages in the waters of Tanjung Priok Harbour in Jakarta, Indonesia. Phytoplankton samples were collected between November 2011 to October 2012 from four ports of Tanjung Priok Harbour and from discharged ballast water of randomly selected ships in the port. Skeletonema, Thalassiosira, and Chaetoceros were three predominant phytoplankton genera in all samples. Ceratium and Protoperidinium were also commonly found in high densities in

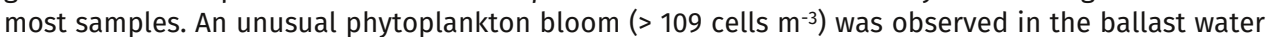
sample taken in March 2012. It was unknown whether this bloom was formed inside the tank or was already present at the source. Ballast water samples of BWD11, BWM12, and BWA12 had significantly different phytoplankton community from the natural assemblages in the harbour, which increase the risk of non-indigenous phytoplankton introduction to Tanjung Priok Harbour.
\end{abstract}

(c) The Author(s) 2018. This article is distributed under a Creative Commons Attribution-ShareAlike 4.0 International license.

\section{INTRODUCTION}

Ship's ballast water has been suggested as the main cause of jump dispersal event for many aquatic organisms. Studies of ballast water in various countries have shown that ships facilitate the transfer of many phytoplankton species across natural barriers (Carlton 1985; Cohen 1998; Gollasch et al. 2000; Couts et al. 2003; David et al. 2007). In many cases, non-indigenous species has caused problematic phenomena, such as harmful algal blooms (HABs) that has negative impacts for natural environments, human health, as well as economic loss (David et al. 2007; Choi 2009). Although the environmental conditions inside ballast tanks may not be favourable for the growth of many phytoplankton cells, many of them are capable on forming a resting stage (cysts or spores) in extreme conditions (Cohen 1998; Gollasch et al. 2000; Choi 2009). Some phytoplankton species, especially the diatoms, could even survive in planktonic form in the absence of light, extreme temperature, and extreme salinity inside ballast tanks (Gollasch et al. 2000).

Tanjung Priok Harbour in Jakarta Bay is one of the busiest international ports in Indonesia and is part of a eutrophic coastal ecosystem (Sidabutar 2010). Cases of phytoplankton bloom, followed by mass fish mortality have occurred several times in Jakarta Bay (Thoha et al. 2007; Sidabutar 2010). The most recent case of mass fish mortality, due to mixed blooms involving two diatom genera Skeletonema and Chaetoceros, occurred in May and September 2007 (Thoha et al. 2007). More than 10,000 vessels from various countries and regions of Indonesia utilise Tanjung Priok Harbour every year (Anonymous, 2006). Due to lack of strict laws on ballast water management, many vessels discharge ballast water inside the port, thus increasing the risk of introducing non-indigenous and harmful phytoplankton species to the ecosystem of Jakarta Bay. The aim of this research is to determine the community structure of phytoplankton in the ships' ballast water in comparison with naturally occurring phytoplankton in Tanjung Priok Harbour.

\section{MATERIALS AND METHODS}

\subsection{Location and time}

This research was conducted from November 2011 to October 2012 in Tanjung Priok Harbour, the largest national and international port in Jakarta. There were four sampling stations in this research: Ports 1-3 and Docking Port (Figure 1). Ballast water from the ships in the port was also treated as a specific sampling station. Foreign registered large tankers and cargo ships used Port 1 while Ports 2 and 3 were used by ships originating from within Indonesia (Figure 1). The Docking Port sampled in this study was located next to the Port 3 (Figure 1) where vessel maintenance works are carried out.

\subsection{Phytoplankton sampling of port and ballast water}

Phytoplankton samples were collected by vertical tow from the depth of $10 \mathrm{~m}$ using a Kitahara plankton net (mesh size $80 \mu \mathrm{m}$, ring $30 \mathrm{~cm}$, length $1 \mathrm{~m}$ ) in the port waters of Tanjung Priok Harbour. Sample collection for ballast water was conducted on one randomly selected foreign registered ship in the international port (Port 1) (Table 1). However, due to difficulties in obtaining permission to get on board the vessels, phytoplankton 

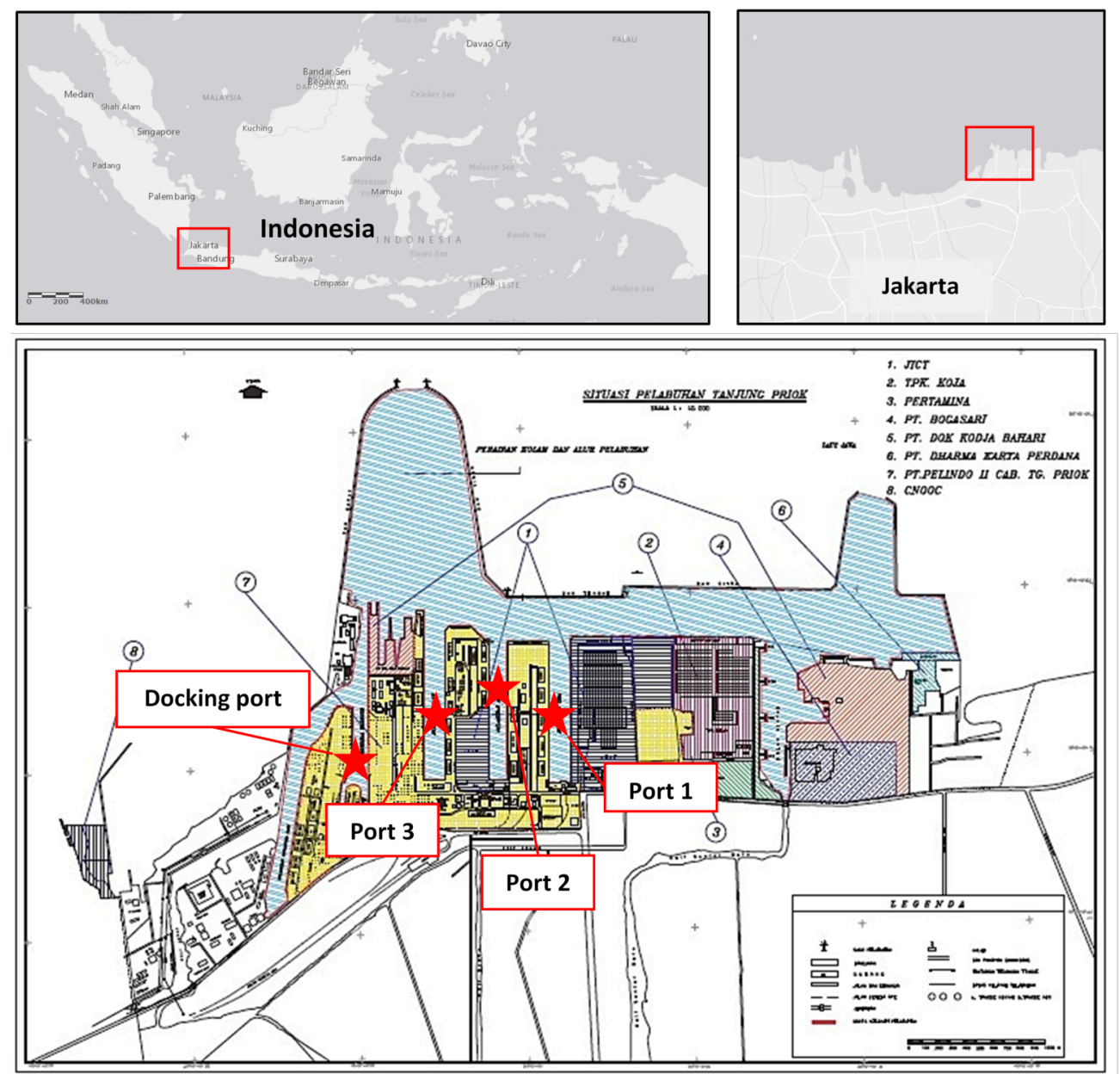

Figure 1. Location of sampling stations (as indicated by red stars) in Tanjung Priok Harbour, Jakarta, Indonesia.

sampling for ballast water was conducted by collecting water discharged from the ballast tanks of the ship, using a modified polycarbonate water sampler. The sample was then concentrated using a hand plankton net (mesh size $20 \mu \mathrm{m}$, ring $15 \mathrm{~cm}$, length $45 \mathrm{~cm}$ ). Concentrated samples from both vertical haul and ballast water samples were preserved by adding $2 \mathrm{~mL}$ of $40 \%$ buffered formaldehyde solution per $100 \mathrm{~mL}$ sample (Edler and Elbrachter 2010).

\subsection{Phytoplankton identification and enumeration}

Identification and enumeration of phytoplankton cells in the samples were conducted by the fractionation method. This was conducted by removing $0.1 \mathrm{~mL}$ of sample using a stamp pipette and placing the sample into a Sedgwick Rafter Counting Chamber (SRCC). In the case of very dense phytoplankton samples, serial dilution up to $10^{-3}$ was conducted. The sample in SRCC was then observed under 100-200x magnification with a Nikon Photophot-2 microscope. Phytoplankton were identified to genus using morphological characters with reference to Davis (1955), Yamaji (1966), Shirota (1966), Nontji (2008), Praseno and Sugestiningsih (2000), and Tomas (1997).

\subsection{Data analysis}

The number of phytoplankton cells in the samples was then converted into cells $\mathrm{m}^{-3}$, using a modified formula of Arinardi (1997), and Semina (1978). The data on phytoplankton community structure was analysed by calculating its relative density according to Cox (1976). A non-metric multidimensional scaling analysis (n-MDS)

Table 1. Details on the ships sampled in this study. Due to permit issues, the ships' log containing details on any ballasting activities could not be obtained.

\begin{tabular}{|c|c|c|c|c|c|}
\hline Sample Code & Sampling Date & Vessel Type & Size (length $\mathrm{x}$ width) $(\mathrm{m})$ & Gross Tonnage (ton) & Nationality ${ }^{(1)}$ \\
\hline BWN11 & $17 / 11 / 2011$ & Container & $115 \times 18$ & 6,251 & Indonesia \\
\hline BWD11 & $19 / 12 / 2011$ & Container & $183 \times 28$ & 16,708 & South Korea \\
\hline BWJ12 & $19 / 01 / 2012$ & Container & $211 \times 32$ & 32,114 & Singapore \\
\hline BWF12 & $15 / 02 / 2012$ & General Cargo & $121 \times 18$ & 7,243 & Panama \\
\hline BWM12 & $14 / 03 / 2012$ & General Cargo & $121 \times 18$ & 7,243 & Panama \\
\hline BWA12 & $17 / 04 / 2012$ & General Cargo & $108 \times 17$ & 4,025 & Indonesia \\
\hline BWMy12 & $16 / 05 / 2012$ & General Cargo & $110 \times 19$ & 7,513 & Panama \\
\hline BWJu12 & $12 / 06 / 2012$ & General Cargo & $110 \times 19$ & 7,513 & Panama \\
\hline BWJI12 & $16 / 07 / 2012$ & General Cargo & $128 \times 20$ & 9,873 & China \\
\hline
\end{tabular}

(1)Ship's nationality or origin at the date of sampling. 

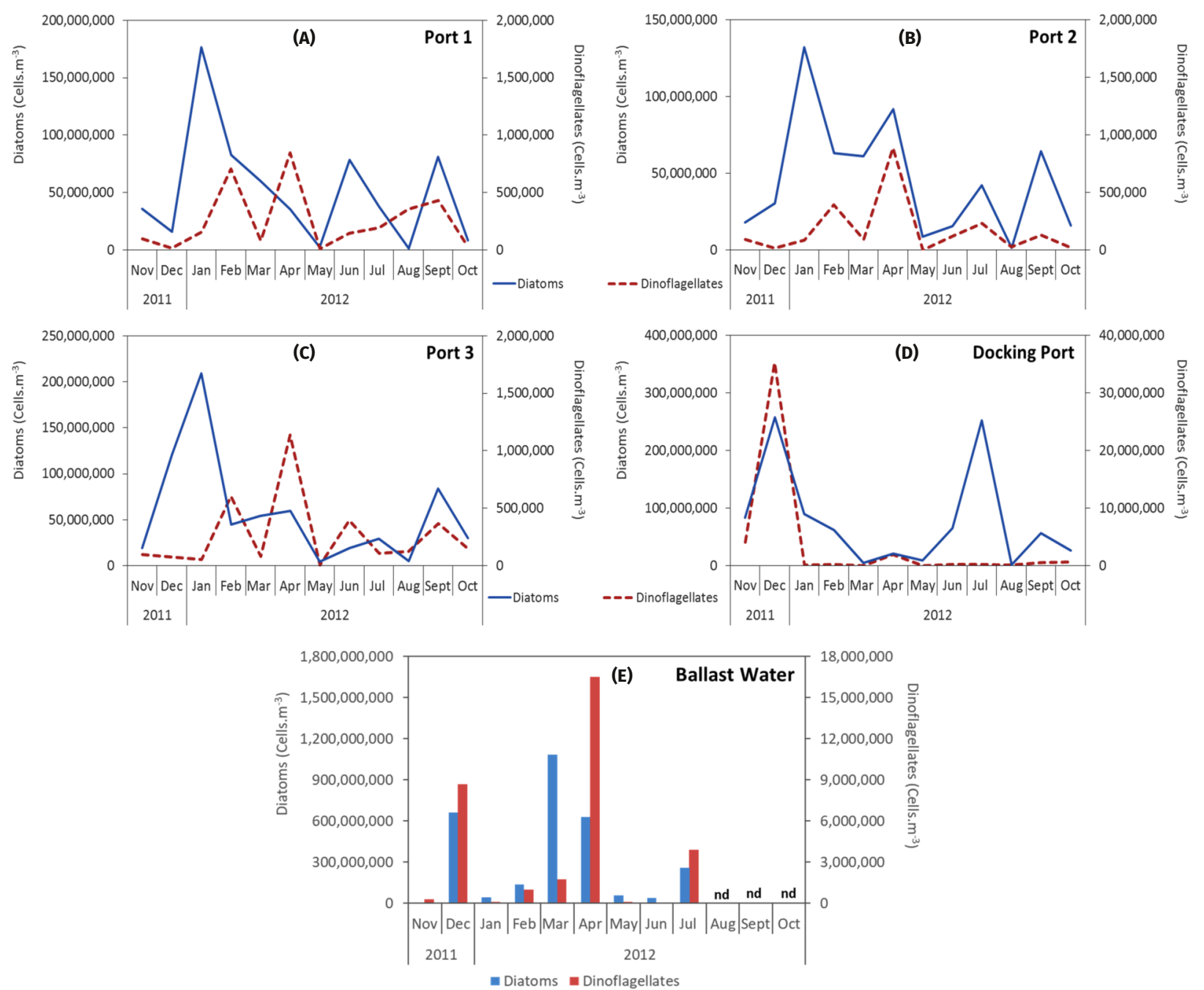

Figure 2. Phytoplankton population dynamics at Tanjung Priok Harbour, Jakarta Bay, Indonesia (see Figure 1 for locations). Cyclic population growth and decline of diatoms and dinoflagellates were observed in (A) Port 1; (B) Port 2; (C) Port 3; (D) Docking Port; (E) Ballast water samples from ships (see Table 1) (nd = no data).

using Euclidean distance (Bakus 2007) was conducted using SPSS ver. 17 to measure the similarities between phytoplankton community in Tanjung Priok Harbour and ballast water.

\section{RESULTS AND DISCUSSION}

\subsection{Phytoplankton dynamics in port and ballast water at Tanjung Priok Harbour}

Results showed different dynamic patterns in the phytoplankton community of Tanjung Priok Harbour (Figure 2). In general, a cyclic population growth pattern was observed in all Ports, with high and low density of cells observed almost at regular intervals (Figure 2). Similar to the general trend found in Jakarta Bay (Thoha, 2010), diatom cell density was much higher than dinoflagellates in this study (Figure 2). The density of diatoms in Tanjung Priok Harbour varied between $1,161,017$ to $56,531,073$ cells $\mathrm{m}^{-3}$, whilst the density of dinoflagellates was observed to be from 0 to 848,656 cells $\mathrm{m}-3$. In most sampling sites (ports) in the Tanjung Priok Harbour, the population dynamics of dinoflagellates were also different from diatoms (Figure 2A-D).

The highest diatom densities in Ports 1 to 3 occurred in January 2012 (Figure 2A-C) and were observed to be $176,690,240$ cells $\mathrm{m}^{-3}, 132,050,919$ cells $\mathrm{m}^{-3}$, and 209,306,931 cells $\mathrm{m}^{-3}$ at Ports 1,2 and 3 respectively. In contrast, the highest diatom density was observed twice, in December 2011 and July 2012 at the docking port (Figure 2D). The density of diatoms at the Docking Port in December 2011 was $257,750,000$ cells $\mathrm{m}^{-3}$, while in July 2012 the diatom cell density was $252,700,565$ cells $\mathrm{m}^{-3}$. Dinoflagellates also seemed to display cyclic population dynamics, with shorter density peak intervals compared to the diatoms (Figure 2). In general, the highest density of dinoflagellates was observed in April 2012, with the exception of Docking port where the highest density of dinoflagellates occurred in December 2011 (Figure 2). The density of dinoflagellates during April 2012 in Ports 1, 2 and 3 were 848,656 cells m ${ }^{-3}$, 884,017 cells m$^{-3}$, and 80,808 cells $\mathrm{m}^{-3}$, respectively. On the other hand, the density of dinoflagellates during December 2011 in Docking Port was 35,250,000 cells m ${ }^{-3}$.

Our results showed that the highest density of diatoms in ballast water occurred in March 2012 (Figure 2), with values exceeding 109 cells $\mathrm{m}^{-3}$. Meanwhile, the highest density of dinoflagellates in ballast water was observed in April 2012 (Figure 2), with a density of 16,500 cells $\mathrm{m}^{-3}$. It was important to note that the highest density of dinoflagellates in ballast water during April 2012, was coincided with its highest density in port 1, 2, and 3 (Figure 2). It was unknown whether the peak in dinoflagellates density in port 1, 2, and 3 during April 2012 was related to ballast water discharge into the water. However, it is also 
(A)

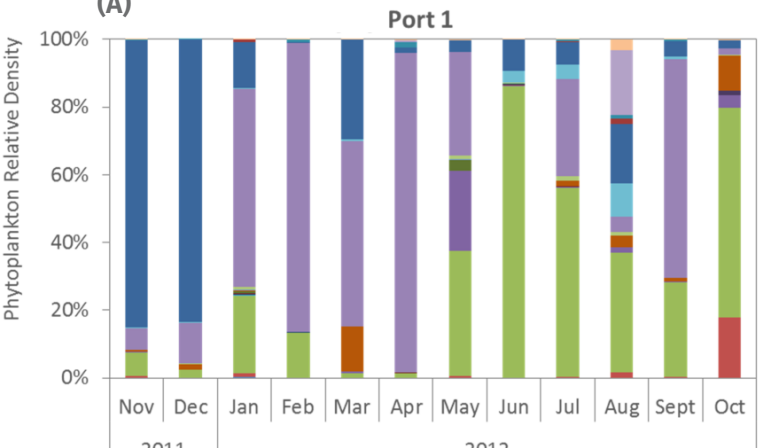

(c)

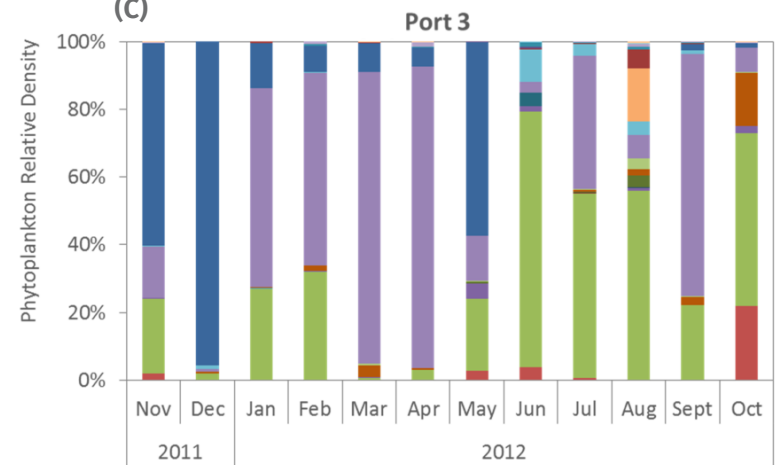

(E)

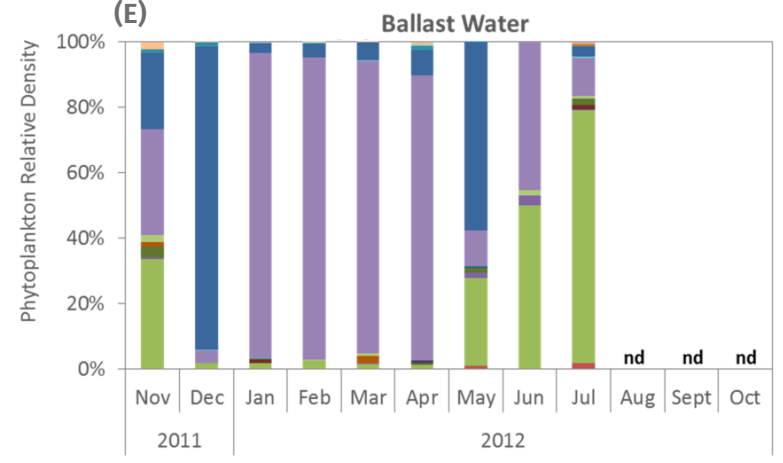

(B)

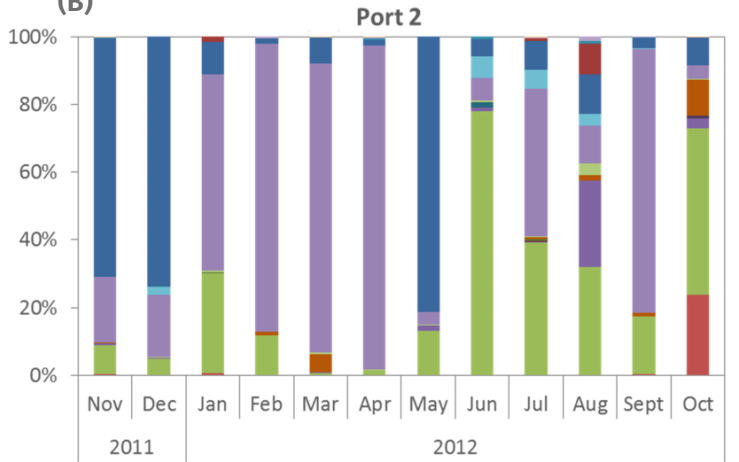

(D)

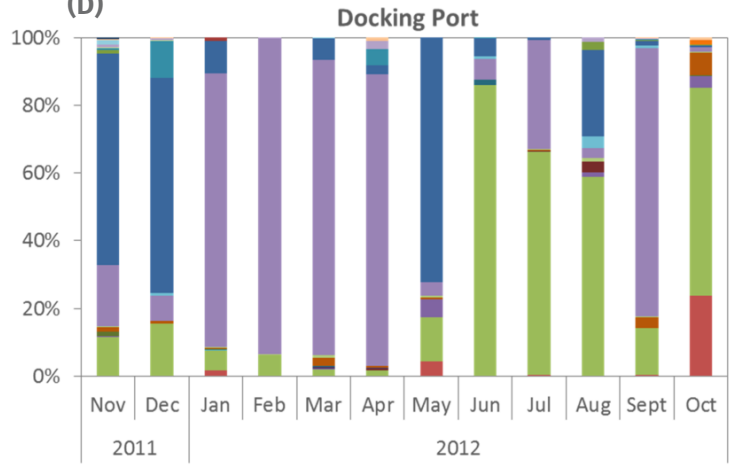

- Coscinodiscus

- Bacteriastrum

- Chaetoceros

- Dytilum

- Eucampia

- Guinardia

- Hemiaulus

- Lauderia

- Leptocylindrus

- Navicula

- Nitzschia

- Odontela

- Pleurosigma

- Streptotheca

- Rhizosolenia

- Skeletonem

- Thalassiothrix

- Thalassionema

- Thalassiosira

- Ceratium

- Alexandrium

- Amphizolenia

- Gonyaulax

- Dinophysis

- Diplosalis

- Prorocentrum

- Gymnodinium

- Protoperidinium

Figure 3. Phytoplankton community structure observed at four locations and in ballast water from ships in Tanjung Priok Harbour, Jakarta Bay, Indonesia. Skeletonema, Thalassiosira, and Chaetoceros comprised the three predominant phytoplankton genera seen in this study. (A) Port 1; (B) Port 2; (C) Port 3; (D) Docking Port; (E) Ballast water, taken from different ships each month (Table 1). nd = no data.

\section{Euclidean distance model}

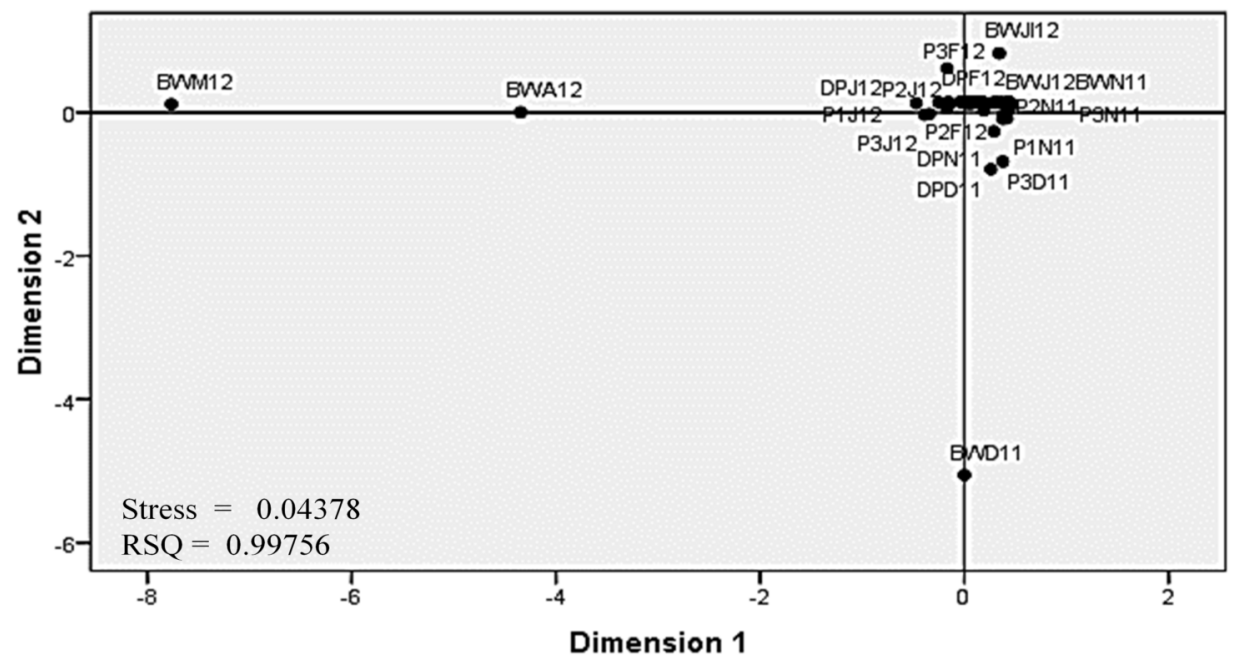

Figure 4. Result of an n-MDS analysis for phytoplankton communities examined from Ports 1-3, Docking Port and ship ballast water in Tanjung Priok Harbour, Jakarta Bay, Indonesia. The community structure of three ballast water samples (BWA12, BWM12, and BWD11) were different from all other samples examined. 
possible that the peak density of dinoflagellates in the ballast water was caused by ships taking ballast water from the port's water. Unfortunately, it was not possible to clearly determine whether the ballast water sample collected during April 2012 was from the tanks filled with Tanjung Priok waters. The density of dinoflagellates found in ship's ballast water, which come to the Tanjung Priok Harbour, was increasing steadily since January 2012 to March 2012 (Figure 2).

In this study, it was not surprising to note that the densities of diatoms and dinoflagellates in the ship's ballast water were very high (Figure 2), and these figures were clearly way beyond the accepted levels stipulated by IMO G8 (D-2) regulations (IMO, 2008). This condition was caused by the lack of regulation on ballast water management in Indonesian ports, including Tanjung Priok Harbour in this study. This has caused the ships that came into the port to be able to discharge the ballast inside the port area, thus increasing the risk of introducing non-indigenous species into the ecosystem.

\subsection{Phytoplankton community structure in port and ballast water at Tanjung Priok Harbour}

The results showed that phytoplankton community structure differed across all sampling sites (Figure 3). In general, Skeletonema, Chaetoceros, and Thalassiosira predominated the phytoplankton community in Tanjung Priok Harbour (Figure 3A-C). Thalassiosira was found in high densities in all ports in Tanjung Priok Harbour during November to December 2011 (Figure 3). After that, the dominance of Thalassiosira was replaced by Skeletonema from January to April 2012 (Figure 3). Another bout of high Thalassiosira dominance was observed in May 2012, but only at Port 2 and 3, and Docking Port (Figure 3B-D). During the adjacent month, the phytoplankton community in Port 1 was pre-dominated by Chaetoceros, Skeletonema, and Coscinodiscus (Figure 3A). Chaetoceros started to pre-dominate the community in June 2012 but its domination was gradually decreased in the following month until September 2012 (Figure 3). Bacteriastrum, a common and abundant phytoplankton genus in Jakarta Bay (Thoha 2010), was only able to pre-dominate the community in October 2012 (Figure 3). The changes in phytoplankton community structure in Tanjung Priok Harbour waters might be related to the change of season. Chaetoceros seemed to be more abundant in the port waters during the dry season in June to August 2012 (Figure 3 ), when higher salinity and temperature conditions occur. In contrast, high dominance of Skeletonema might be related to increasing freshwater input and lower salinity during the wet season (December to February) and intermediate season I (March to May) (Figure 3). However, it was unclear why the density of Thalassiosira relative suddenly increased in May 2012 (Figure 3).

Similar to the phytoplankton community in the port waters, the community in ballast water was also dominated by diatoms (Figure 3E). Skeletonema, Chaetoceros, and Thalassiosira were the three dominant phytoplankton genera in the ballast water of ships (Figure 3E). Dinoflagellates were also present in ballast water samples, but only Ceratium and Protoperidinium were common. However, the number of genera present in ballast water was lower than in port waters. The number of genera present in all ports of Tanjung Priok in all months was varied between 9 to 19 genera, while in ballast water the highest number of genera present was only 12 . This showed that only few phytoplankton genera are capable of surviving the unfavourable water conditions inside ballast tanks. However, a study on ballast water in Germany suggested that phytoplankton not only capable to survive in the ballast, some species might even can reproduce inside the ballast tanks (Gollasch 1996; Cohen 1998; Gollasch et al. 2000; David et al. 2007). Some diatoms such as Pseudo-nitzschia, Hemiaulus, Rhizosolenia, and Thalassiosira are known to survive in the ballast water tanks for over 100 days (Gollasch et al. 2000). In this study, potentially harmful genera, such as Dinophysis and Prorocentrum were present in the sample, but their absolute and relative densities were very low compared to diatoms (Figure 3E). Unfortunately, due to legal issues, the sediment from the bottom of the ballast tank could not be sampled to observe the cyst bank that might formed inside the tanks. Thus the number of genera that were observed might not be representative of the true phytoplankton community structure in the ballast tank.

Based on the result of the n-MDS analysis, it was found that most of the ships' ballast water sampled in this study has similar phytoplankton community structure with Tanjung Priok Harbour waters (Figure 4). That trend confirmed our earlier assumption that some of the ships that were sampled in this study did take some ballast water from the port. However, ballast water sampled in December 2011 (BWD11), March 2012 (BWM12), and April 2012 (BWA12) possessed significantly different phytoplankton community structures compared to the other sampling sites (Figure 4). This suggests that the phytoplankton community inside the ballast water of ships sampled during that time did not come from the water inside the Tanjung Priok ports or Jakarta Bay.

According to ship data shown in Table 1, BWD11, BWM12, and BWA12 samples were taken from ships with the national flag of South Korea, Panama, and Indonesia. Unfortunately, due to legal issues, details on the ballasting activities and last port of those ships were not available for this study. Therefore, it was hard to determine whether the unique phytoplankton communities in the samples (Figure 4) were originated from those countries. Even so, the result of the n-MDS analysis did strongly suggest that the phytoplankton communities found in BWD11, BWM12, and BWA12 were different from those found in Tanjung Priok Harbour.

In this study, ballast water samples in December 2011 (BWD11) had one of the highest densities of both dinoflagellates and diatoms (Figure 2E) compared to other samples (Figure 2A-D). The density of diatoms in the sample was over $6 \times 108$ cells $\mathrm{m}^{-3}$, while the dinoflagellate cell density was over $8 \times 106$ cells $^{-3}$ (Figure 2E). In BWD11, the most abundant diatom genus was Thalassiosira, with a density of $621,900,000$ cells $\mathrm{m}^{-3}$ (Figure 3E). Meanwhile, dinoflagellate community in BWD11 sample consisted of only two genera, Ceratium, with a density of $8,400,000$ cells $\mathrm{m}^{-3}$, and Protoperidinium, with a density of 300,000 cells $\mathrm{m}^{-3}$. The phytoplankton community in BWD11 was significantly different from the natural assemblages in the ports due to high density ( $>105$ cells $\mathrm{m}^{-3}$ ) of Guinardia, Lauderia, and Navicula in the sample. Those three diatoms were not present in the ports water in December 2011.

Ballast water samples in March 2012 (BWM 12) had the highest density of diatom cells (Figure 2). This sample was also characterized by having a high dominance of Skeletonema (Figure 3E). With a density over 109 cells $\mathrm{m}^{-3}$ (Figure 2E), a Skeletonema-dominated phytoplankton bloom event seemed to have occurred inside the ballast 
tank, which is quite unusual. It was unknown whether this bloom developed inside the tank or there was a bloom event in the source water. Skeletonema is generally known as a cosmopolitan diatom that are frequently found in ballast water tanks of some trans-Pacific ships. It has been suggested that they have specific metabolic strategies to deal with absence of sunlight and nutrient deficiency inside the ballast tanks (Klein et al. 2010). Thus, it is possible that extreme conditions in the ballast tanks reduced the predation rate by zooplankton and competition rate, allowing Skeletonema to form blooms inside the tanks.

On the other hand, ballast water sample in April 2012 (BWA12) has the highest density of dinoflagellates (Figure 2E) than in the adjacent month (Figs. 2A-D). The density of dinoflagellates in the April 2012 ballast water sample was more than $16 \times 106$ cells m$^{-3}$ (Figure 2E). Phytoplankton community in the BWA12 sample was very different from others due to the high abundance of Ceratium, Protoperidinium, and Prorocentrum, which have densities of 9,900,000 cells $\mathrm{m}^{-3}, 4,200,000$ cells $\mathrm{m}^{-3}$, and 1,200,000 cells $\mathrm{m}^{-3}$, respectively. In this case, Protoperidinium was one among few genera of dinoflagellates that tend to survive a long voyage inside the ballast water tanks, most likely due to its heterotrophic characteristics (Hallegraef 1998). On the other hand, Ceratium and Prorocentrum were two harmful dinoflagellates that often remained inside the ballast water tanks of trans-Pacific ships, even after the ship has undergone the open ocean ballast water exchange (OOBW) process (Zhang and Dickman 1999). By taking account of their survivability, the ballast tanks would act as a jump dispersal medium for Ceratium, Prorocentrum, and Protoperidinium, which later could easily be introduced to Tanjung Priok waters.

\subsection{Potential dangers of introduced phytoplankton from ballast water}

The result of this research suggested that the likelihood of an exotic species bloom in the Tanjung Priok Harbour seems likely. Furthermore, three ballast water samples from different ships with different nationality, have unique phytoplankton communities that are significantly different from the those of Tanjung Priok Harbour. In this case, exotic or non-indigenous species will enter the ecosystem by ballast water discharge from the foreign ships in the ports. Although the general survival rate for phytoplankton in ballast water was only $0.2 \%$ (Gollasch et al. 2000), some dinoflagellates could survive in the form of resting cysts in the deposited sediment at the bottom of the ballast tank (Hallegraeff 1998; David et al. 2007). Many of those cysts are viable and can germinate after discharge from the ballast tank to the port water (Hallegraeff 1998). However, the bloom of dinoflagellates that emerge from the cyst stored in ballast water might not occur immediately in the new ecosystem. Research in Tasmania showed that the introduction of Gymnodinium catenatum in 1972 required eight years to cause the first bloom event in 1980 (Hallegraeff et al. 1988; Hallegraeff 1998; McMinn et al. 1998).

Aside from dinoflagellates, some harmful diatoms, such as Pseudo-nitzschia, are known to survive a long journey inside the ballast water tanks (Hyun et al. 2016). There was a case where Pseudo-nitzschia was exported from Pasaia Harbour in Spain to St. Lawrence Seaway in Canada (Butron et al. 2011). Thus, phytoplankton discharged from ship's ballast water in Tanjung Priok Harbour might not pose an immediate danger but has chances to create ecological problems in the future.
Based on the study by Hallegraeff (1998), the introduced phytoplankton species from the ballast water might take 10 to 20 years to form a successful germination in Tanjung Priok Harbour. When the adapted generation of phytoplankton cells formed, the non-indigenous species might begin to bloom in the environment and cause severe economic damage.

\section{CONCLUSIONS}

The results of this study strongly suggest a possible introduction of non-native phytoplankton communities into the waters of Tanjung Priok Harbour. That was due to the finding of unique phytoplankton community structure, which was significantly different from the one found in the waters of the harbour. Combined with the high density of phytoplankton observed in ballast water samples, it was suggested that the risk of invasion by exotic phytoplankton species in Tanjung Priok Harbour water is high. Unfortunately, it was not known whether the phytoplankton species found both in ballast water or port's waters were native or introduced. Even so, it becomes very important to rapidly establish a ballast water management system in the port, in order to prevent or mitigate the negative impact of invasive phytoplankton species from the ships' ballast water.

\section{ACKNOWLEDGEMENTS}

This study was funded and conducted as part of ASEANIndia Cooperation Project 2011-2012 "Extent of transfer of alien invasive organisms in South/Southeast Asia region by shipping". We would like to express our gratitude towards Ms Elly Asnaryanti, Ms Trimaningsih, and Ms Sugestiningsih, our laboratory technicians who have greatly assisted us both in the field sampling and laboratory analysis. Likewise, we thank our colleagues in the Plankton and Primary Productivity Laboratory RCO-LIPI, Ms Nurul Fitriya and Mr Tumpak Sidabutar, for their assistance in field sampling and insights during data analysis. We are also grateful to our colleagues in the Benthos Laboratory RCO-LIPI and the Nutrient Laboratory RCO-LIPI for their assistance in field sampling and insight during the data analysis process. Permission was granted by the Tanjung Priok Port Authority/Harbour Master (Syahbandar) to conduct the study in Tanjung Priok Harbour. The Indonesian Water Police (Polisi Air) provided assistance in the field sampling.

\section{REFERENCES}

Anonymous. 2006. Informasi 25 pelabuhan strategis Indonesia: Pelabuhan Tanjung Priok. Jakarta: PT. Pelabuhan Indonesia II.

Arinardi OH. 1997. Metode penelitian plankton bahari. In: Hutagalung HP, Setiapermana D, Riyono SH, editors. Metode analisis air laut, sedimen dan biota: buku 2. Jakarta: Pusat Penelitian dan Pengembangan Oseanologi LIPI. p. 143-152

Bakus GJ. 2007. Community analysis: ordination and other multivariate techniques.In: Bakus GJ, editor. Quantitative analysis of marine biological communities: field biology and environment. New Jersey: John Wiley \& Sons. p. 237-263.

Butron A, Orive E, Madariaga I. 2011. Potential risk of harmful algae transport by ballast waters: the case of Bilbao Harbour. Marine Pollution Bulletin 62:747-757. 
Carlton JT. 1985. Transoceanic and interoceanic dispersal of coastal marine organisms: the biology of ballast water. Oceanography and Marine Biology Annual Review 23:313-374.

Choi KH. 2009. Risk assessment of ballast water-mediated invasion of phytoplankton: a modelling study. Ocean Science Journal 44(4):221-226.

Cohen AN. 1998. Ships' ballast water and the introduction of exotic organisms into the San Francisco estuary: current status of the problem and options for the management. Richmond: San Francisco Estuary Institute.

Couts ADM, Kirrily MM, Chad LH. 2003. Ships' sea-chests: an overlooked transfer mechanism for nonindigenous marine species. Marine Pollution Bulletin 46(11):1510-1513.

Cox GW. 1976. Laboratory manual of general ecology 3rd edition. Iowa: W.C. Brown Company Publishing.

David M, Gollasch S, Cabrini M, Perkovic M, Bosnjak D, Virgilio D. 2007. Results from the first ballast water sampling study in the Mediterranean Sea - the Port of Koper study. Marine Pollution Bulletin (54):53-65.

Davis CC. 1955. The marine and freshwater plankton. East Lansing: Michigan State University Press.

Edler L, Elbrachter M. 2010. The utermohl method for quantitative phytoplankton analysis. In: Karlson B, Cusack C, Bresnan E, editors. Microscopic and molecular methods for quantitative phytoplankton analysis. Spain: Intergovernmental Oceanographic Commission, United Nations Educational, Scientific and Cultural Organization. p. 13-15

Gollasch S. 1996. Untersuchungen des Arteintrages durch den internationalen Schi sverkehr unter besonderer Berücksichtigung nichtheimischer [dissertation]. Universitaet Hamburg. Hamburg: Verlag Dr. Kovac.

Gollasch S, Lenz J, Dammer M, Andreas HG. 2000. Survival of tropical ballast water organisms during a cruise from the Indian Ocean to the North Sea. Journal of Plankton Research 22:923-937.

Hallegraeff GM. 1998. Transport of toxic dinoflagellates via ships' ballast water: bioeconomic risk assessment and efficacy of possible ballast water management strategies. Marine Ecology Progress Series 168:297-309.

Hallegraeff GM, Steffensen DA, Wetherbee R. 1988. Three estuarine Australian dinoflagellates that can produce paralytic shellfish toxin. Journal of Plankton Research 10:533-541.

Hyun B, Shin K, Jang M-C, Jang P-G, Lee W-J, Park C, Choi K-H. 2016. Potential invasions of phytoplankton in ship ballast water at South Korean ports. Marine and
Freshwater Research 67:1906-1917.

[IMO] International Maritime Organization. 2008. Annex 3 Resolution MEPC.173(58): guidelines for ballast water sampling (G2). London: International Maritime Organization; [accessed 2013 Nov 25]. http://www.imo.org/blast/blastDataHelper.asp?dat a_id=23757\&filename $=173 \% 2858 \% 29$.pdf.

Klein G, Macintosh K, Kaczmarska I, Ehrman JM. 2010. Diatom survivorship in ballast water during trans-Pacific crossings. Biological Invasions 12:1031-1044.

McMinn A, Hallaegreff GM, Thomson P, Jenkinson AV, Heijnis H. 1998. Cyst and radionucleotide evidence for the recent introduction of the toxic dinoflagellate Gymnodinium catenatum into Tasmanian waters. Marine Ecology Progress Series 161:165-172.

Nontji A. 2008. Plankton laut. Jakarta: LIPI Press.

Praseno DP, Sugestiningsih. 2000. Retaid di perairan Indonesia. Jakarta: Pusat Penelitian dan Pengembangan Oseanologi LIPI.

Semina HJ. 1978. Using the standard microscope: treatment of an aliquot sample. In: Sournia A, editor. Phytoplankton manual. France: United Nations Educational, Scientific and Cultural Organization. p. 181.

Shirota A. 1966. The plankton of South Vietnam: freshwater and marine plankton. Japan: Overseas Technical Cooperation Agency.

Sidabutar T. 2010. Kondisi fitoplankton di Teluk Jakarta pada periode 2008-2009. In: Muchsin R, editor. Dinamika ekosistem perairan Kepulauan Seribu, Teluk Jakarta. Jakarta: Pusat Penelitian Oseanografi Lembaga Ilmu Pengetahuan Indonesia.

Thoha H, Adnan Q, Sidabutar T, Sugestiningsih. 2007. Note on the occurrence of phytoplankton and its relation with mass mortality in the Jakarta Bay, May and November 2004. Makara Seri Sains 11:63-67.

Thoha H. 2010. Studi variasi musiman terhadap kelimpahan fitoplankton di perairan Teluk Jakarta 2009. In: Muchsin R, editor. Dinamika ekosistem perairan Kepulauan Seribu, Teluk Jakarta. Jakarta: Pusat Penelitian Oseanografi Lembaga Ilmu Pengetahuan Indonesia. p. 139-146.

Tomas CR. 1997. Identifying marine phytoplankton. San Diego: Academic Press.

Yamaji I. 1966. Illustrations of the marine plankton of Japan. Japan: Hoikusha.

Zhang F, Dickman M. 1999. Mid-ocean exchange of container vessel ballast water: 1 . Seasonal factors affecting the transport of harmful diatoms and dinoflagellates. Marine Ecology Progress Series 176:243-251. 
